\title{
Efektivitas Pelatihan Contextual Teaching and Learning (CTL) Guna Meningkatkan Kompetensi Pedagogik Guru Sekolah Dasar di Pulau Sebatik
}

\author{
Yusandi Rezki Fadhli ${ }^{1 *}$, Nono Hery Yoenanto ${ }^{2}$ \\ ${ }^{12}$ Fakultas Psikologi, Universitas Airlangga Surabaya. Indonesia \\ Email: yusandi.rezki.fadhli-2016@ psikologi.unair.ac.id ${ }^{1}$,nono.hery@psikologi.unair.ac.id ${ }^{2}$

\begin{abstract}
Competency pedagogic is the ability to manage the learning of participants learners that includes an understanding of the participant students, The design and implementation of learning, evaluation of the results of learning, and the development of the participant students to actualize various potentials that its. This study aims to determine the effectiveness of Contextual Teaching and Learning training to improve the pedagogical competence of elementary school teachers on Sebatik Island. Mechanical collection of data in the form of tool measuring scale Likert, a matter of knowledge and observation guide. Design research that is used is pretest-posttest one group design with a number of subjects as much as 30 teachers of the school base. This study uses the analysis of the Wilcoxon signed rank test. The results of the analysis of the data shows the value of significance $0.000<0.05$ which means that there are differences in the mean scores of competence pedagogic between the results of the pretest participants of the training contextual teaching and learning with the results of the posttest participant training contextual teaching and learning.
\end{abstract}

Keywords: Teacher school elementary, learning, method, contextual teaching and learning (CTL), Sebatik Island .

\begin{abstract}
ABSTRAK
Kompetensi pedagogik adalah kemampuan mengelola pembelajaran peserta didik yang meliputi pemahaman terhadap peserta didik, perancangan dan pelaksanaan pembelajaran, evaluasi hasil belajar, dan pengembangan peserta didik untuk mengaktualisasikan berbagai potensi yang dimilikinya. Penelitian ini bertujuan untuk mengetahui efektivitas pelatihan contextual teaching and learning (CTL) untuk meningkatkan kompetensi pedagogik guru sekolah dasar di pulau Sebatik. Teknik pengumpulan data berupa alat ukur skala likert, soal pengetahuan dan pedomen observasi. Desain penelitian yang digunakan adalah pretest-posttest one group design dengan jumlah subjek sebanyak 30 orang guru sekolah dasar. Penelitian ini menggunakan analisis teknik uji Wilcoxon signed rank test. Hasil analisis data menunjukkan nilai signifikansi 0,000 <0,05 yang berarti terdapat perbedaan rerata skor kompetensi pedagogik antara hasil pretest peserta pelatihan contextual teaching and learning (CTL) dengan hasil posttest peserta pelatihan contextual teaching and learning (CTL).
\end{abstract}

Kata Kunci: Kompetensi pedagogik guru sekolah dasar, metode pembelajaran, Contextual teaching and learning (CTL), Pulau Sebatik. 


\section{PENDAHULUAN}

Wilayah perbatasan merupakan beranda terdepan Indonesia menjadi pagar dalam menjaga kedaulatan bangsa sekaligus gudang terbelakang dalam pembangunan nasional termasuk bidang pendidikan. Namun di Pulau Sebatik ini, pendidikannya sangat berbanding terbalik dengan apa yang terjadi di kota-kota besar, dan negara tetangga yang lokasinya memang tidak begitu jauh dan sangat terlihat jelas. Permasalahan utama yang dapat diperbaiki terlebih dahulu untuk meningkatkan daya saing dengan negara tetangga maupun daerah lainnya adalah memperbaiki kualitas tenaga pengajarnya. Guru sebagai tenaga pengajar merupakan komponen paling utama dalam menentukan sistem pendidikan secara keseluruhan, yang harus mendapat perhatian sentral, pertama, dan utama. Berdasarkan Undang-Undang No. 14 Tahun 2005 tentang guru dan dosen menyatakan bahwa guru adalah pendidik atau guru professional dengan tugas utama mendidik, mengajar, membimbing, mengarahkan, melatih, dan mengevaluasi peserta didik pada Pendidikan anak usia dini, jalur Pendidikan formal, Pendidikan dasar, dan Pendidikan menengah (Kementerian Pendidikan Nasional, 2003).

Guru sebagai tenaga pengajar profesional dituntut untuk minimal memiliki 4 kompetensi. Sesuai Undang-Undang Nomor 14 Tahun 2005 tentang guru dan dosen pasal 1 ayat 10 , kompetensi adalah seperangat pengetahuan, keterampilan, dan perilaku yang harus dimiliki, dihayati, dan dikuasai oleh guru atau dosen dalam melaksanakan tugas keprofesionalan. Seseorang dikatakan kompeten dalam bidangnya jika pengetahuan, keterampilan, dan sikapnya, serta hasil kerjanya sesuai standar yang ditetapkan dan/atau lembaga maupun pemerintah (Ramayulis, 2013).Permendiknas Nomor 16 Tahun 2007, guru harus memiliki empat kompetensi utama yaitu kompetensi pedagogik, kompetensi kepribadian sosial, dan kompetensi profesional. Dalam hal pengajaran, kompetensi pedagogik merupakan salah satu kunci keberhasilan dalam mendidik. Guru yang mempunyai kompetensi tinggi mungkin tidak akan mencapai hasil maksimal tanpa didukung oleh kemampuan pedagogik yang memadai (Sumarjoko, 2018). Dalam hal pengajaran, kompetensi pedagogik merupakan salah satu kunci keberhasilan dalam mendidik. Guru yang mempunyai kompetensi tinggi mungkin tidak akan mencapai hasil maksimal tanpa didukung oleh kemampuan pedagogik yang memadai.

Kompetensi pedagogik erat kaitannya dengan berlangsungnya proses pembelajaran yang efektif dan efisien di kelas karena dalam kompetensi ini terdapat beberapa aspek yang berkaitan langsung dengan peserta didik. Rendahnya kompetensi yang dimiliki guru sekolah dasar di Pulau Sebatik khususnya pada nilai kompetensi pedagogik dapat ditingkankan dengan beberapa metode pembelajaran salah satunya dengan metode contextual teaching and learning (CTL). Contextual teaching and learning (CTL) merupakan suatu model pembelajaran yang memberikan fasilitas kegiatan belajar siswa untuk mencari, mengelolah, dan menemukan pengalaman belajar yang lebih bersifat konkrit dan mengaitkan dengan kehidupan nyata siswa (Komalasari, 2012). Contextual teaching and learning (CTL) juga dapat diartikan suatu konsep belajar yang membantu guru mengaitkan konten mata pelajaran dengan situasi dunia nyata dan memotivasi siswa membuat hubungan antara pengetahuan dan penerapannya dalam kehidupan nyata (Depdiknas, 2008).

Ada lima konsep yang digunakan dalam contextual teaching and learning (CTL), yaitu Relating, Experiencing, Applying, Cooperating, dan Transfering atau disingkat (REACT). Relating adalah bentuk belajar dalam konteks kehidupan nyata atau pengalaman nyata. Pembelajaran harus digunakan untuk menghubungkan situasi sehari-hari dengan informasi baru untuk dipahami atau dengan problema untuk dipecahkan. Experiencing adalah belajar dalam konteks eksplorasi, penemuan, dan penciptaan. Hal ini berarti proses pembelajaran 
lebih mengedepankan proses berpikir kritis lewat siklus inquiry.

Applying adalah belajar dalam bentuk penerapan hasil belajar kedalam penggunaan dan kebutuhan praktis. Dalam praktiknya siswa menerapkan konsep dan informasi kedalam kebutuhan kehidupan mendatang yang dibayangkan Cooperating adalah belajar dalam bentuk berbagi informasi dan pengalaman, saling merespon, dan saling berkomunikasi. Bentuk belajar ini tidak hanya membantu siswa belajar tentang materi, tetapi juga konsisten dengan penekanan belajar kontekstual dalam kehidupan nyata. Selain itu, pembelajaran dengan menggunakan CTL dapat memotivasi siswa untuk mengarahkan pembelajaran mereka sendiri dan menghubungkan antara pengetahuan dan aplikasinya dengan setiap konteks yang ditemukan di dalam kehidupan. Dalam hal ini, para siswa diharapkan belajar melalui "mengalami" bukan dengan "menghafal" bahan pembelajaran (Fadhila, Efendi, \& Ridwan, 2017). Dalam kehidupan yang nyata siswa akan menjadi warga yang hidup berdampingan dan berkomunikasi dengan warga lain sehingga dibutuhkan pembelajaran yang membawa mereka untuk langsung merasakan kegiatan yang berdampingan langsung. Transfering adalah kegiatan belajar dalam bentuk memanfaatkan pengetahuan dan pengalaman berdasarkan konteks baru untuk mendapatkan pengetahuan dan pengalaman belajar yang baru (Mudlofir, 2012).

Trianto (2007) menyatakan bahwa pembelajaran dapat dikatakan menggunakan pendekatan kontekstual apabila dalam proses pembelajaran telah melibatkan tujuh komponen yaitu: konstruktivisme (constructivisme), menemukan inquiry (inquiry), bertanya (questioning), masyarakat belajar (learning comunity), pemodelan (modelling), refleksi (reflection), dan penilaian sebenarnya (authentic assesment). Pembelajaran dengan menggunakan pendekatan kontekstual dapat diterapkan dalam kurikulum apa saja dan di kelas yang bagaimanapun keadannya.

a. Konstruktivisme (Constructivisme)

Konstruktivisme merupakan landasan filosofis (berpikir) pendekatan contextual teaching and learning (CTL). Kontruktivisme menekankan terbangunnya pemahaman sendiri secara aktif, kreatif, dan produktif berdasarkan pengetahuan dan pengetahuan terdahulu dan dari pengalaman belajar yang bermakna. Kegiatan belajar dikemas menjadi proses mengonstruksi pengetahuan sehingga belajar dimulai dari apa yang diketahui peserta didik. Diharapkan peserta didik mampu menemukan ide dan pengetahuan baik konsep maupun prinsip baru, menerapkan ide-ide, kemudian peserta didik mencari strategi belajar yang efektif agar mencapai kompetensi dan memberikan kepuasan atas penemuan (Mulyasa, 2009)

\section{b. Bertanya (Questioning)}

Pengetahuan yang dimiliki seseorang bermula dari "bertanya". Questioning (bertanya) merupakan strategi utama pembelajaran yang berbasis contextual teaching and learning (CTL). Bertanya dalam pembelajaran dipandang sebagai kegiatan guru untuk mendorong, membimbing, dan menilai kemampuan berpikir siswa (Muslich, 2011: 44). Dalam pembelajaran contextual teaching and learning (CTL), guru tidak menyampaikan informasi begitu saja tetapi memancing siswa untuk dapat menemukan sendiri. Oleh karena itu, peran bertanya sangat penting sebagai cara guru untuk membimbing dan mengarahkan siswa menemukan setiap materi yang dipelajarinya (Trianto, 2007).

c. Menemukan (Inquiry)

Menemukan merupakan bagian inti dari kegiatan pembelajaran berbasis contextual teaching and learning (CTL). Kegiatan ini diawali dari pengamatan terhadap fenomena, 
dilanjutkan dengan kegiatan-kegiatan bermakna untuk menghasilkan temuan yang diperoleh sendiri oleh siswa. Pengetahuan dan keterampilan yang diperoleh siswa bukan hasil mengingat seperangkat fakta-fakta, tetapi hasil dari menemukan sendiri. Langkahlangkah kegiatan inquiry yaitu merumuskan masalah, mengamati atau melakukan observasi, menganalisis dan menyajikan hasil, dan mengkomunikasikan hasilnya pada pihak lain (Trianto, 2007).

\section{d. Masyarakat Belajar (Learning Community)}

Merupakan sekelompok orang yang terikat dalam kegiatan belajar sehingga memungkinkan siswa untuk dapat bertukar pengalaman dan berbagi ide antara yang satu dengan yang lain. Konsep masyarakat belajar (learning community) menyarankan agar hasil pembelajaran diperoleh dari kerja sama dengan orang lain. Hasil belajar diperoleh dari sharing antara teman, antar kelompok dan antara yang tahu dan yang belum tahu (Trianto, 2007).

\section{e. Pemodelan (Modelling)}

Pemodelan maksudnya dalam sebuah pembelajaran keterampilan atau pengetahuan tertentu, ada model yang bisa di tiru. Model itu bisa berupa cara mengoperasikan sesuatu, atau guru memberi contoh cara mengerjakan sesuatu. Dalam pembelajaran contextual teaching and learning (CTL) guru bukan satu-satunya model. Model dapat di rancang dengan melibatkan siswa (Trianto, 2007).

\section{f. Refleksi (Reflection)}

Refleksi merupakan proses pengendapan pengalaman yang telah dipelajari dengan cara mengurutkan kembali kejadian-kejadian atau peristiwa pembelajaran yang telah dilaluinya. Dalam pembelajaran contextual teaching and learning (CTL), setiap berakhir proses pembelajaran, guru memberikan kesempatan pada siswa untuk merenung atau mengingat kembali apa yang telah disampaikannya (Trianto, 2007).

\section{g. Penilaian yang sebenarnya (Authentic Assesment)}

Assesment adalah proses pengumpulan berbagai data yang bisa memberikan gambaran perkembangan belajar siswa. Data yang dikumpulkan melalui kegiatan penilaian bukanlah untuk mencari informasi tentang belajar siswa. Pembelajaran yang benar sudah seharusnya ditekankan pada upaya membantu siswa agar mampu mempelajari, bukan ditekankan pada diperolehnya sebanyak-banyak mungkin informasi di akhir pembelajaran (Trianto, 2007).

Berdasarkan penelitian Kasno (2017) kegiatan pendampingan menggunakan model pembelajaran contextual teaching and learning (CTL) yang dilakukan oleh kepala sekolah terbukti efektif meningkatkan kompetensi guru kelas V dalam mengajar di SD Negeri 1 Kebonagung UPTD Pendidikan Kecamatan Tegowanu Kabupaten Grobogan. Kompetensi pedagogik merupakan bagian yang tidak dapat dipisahkan dengan empat kompetensi utama yang dimiliki oleh seorang guru, yaitu kompetensi pedagogik, kompetensi kepribadian, kompetensi sosial, dan kompetensi profesional. Keempat kompetensi tersebut terintegrasi dalam kinerja guru saat melaksanakan profesinya, dapat disimpulkan bahwa kompetensi pedagogik merupakan kemampuan seorang guru dalam mengelola proses pembelajaran peserta didik.

Hasil penelitian juga menunjukkan bahwa variabel contextual teaching and learning (CTL) memiliki pengaruh terhadap variabel kompetensi pedagogik pada guru (Hufri, Amir, Cahyati, Irani, dan Hasibuan, 2018). Selain itu, penelitian serupa juga ditemukan oleh Leigh (2006) 
bahwa pelatihan dapat menghasilkan keterampilan hingga siap untuk bekerja sama dengan pihak lain. Kompetensi pedagogik adalah kemampuan mengelola pembelajaran peserta didik yang meliputi pemahaman terhadap peserta didik, perancangan dan pelaksanaan pembelajaran, evaluasi hasil belajar, dan pengembangan peserta didik untuk mengaktualisasikan berbagai potensi yang dimilikinya (Mulyasa, 2009). Kompetensi pedagogik guru bertujuan dan berfungsi di antaranya: (a) Membantu siswa berkembang secara intelektual, sosial, fisik, dan emosional; (b) Meningkatkan kesan diri siswa (self images); (c) Menyediakan kesempatan untuk sukses; (d) Melaksanakan belajar aktif; (e) Menguatkan eksplorasi; (f) Menyediakan keamanan. Jika kita melihat tujuan dan fungsi telah dipaparkan diatas, maka dapat dikatakan bahwa dengan diterapkannya kompetensi pedagogik oleh guru maka tujuan pendidikan yang diharapkan sekolah dapat tercapai dengan baik (Musfah, 2011).

Penelitian yang lainnya yang menunjukkan bahwa metode belajar contextual teaching and learning (CTL) dapat mempengaruhi kompetensi pedagogik guru adalah Pelatihan penerapan pendekatan kontekstual ini membuka wawasan baru bagi guru-guru tentang metode dan pendekatan dalam pembelajaran untuk meningkatkan kemampuannya dalam mengajar (Nurhaeda, 2012). Berdasarkan hasil penelitian Karim (2017), pelaksanaan pendekatan pembelajaran kontekstual dipengaruhi oleh pendekatan pembelajaran lainnya yang dapat meningkatkan kompetensi guru. Berdasarkan kajian literatur beserta penelitian sebelumnya, sejauh ini kajian tentang efektivitas pelatihan metode pembelajaran contextual teaching and learning (CTL) di berbagai daerah Indonesia masih terbatas di daerah terpencil atau perbatasan. Penelitian tentang efektifitas metode belajar contextual teaching and learning (CTL) lebih banyak dilakukan di daerah perkotaan

\section{METODE}

Penelitian ini menggunakan metode penelitian kuantitatif eksperimen. Pada penelitian kuantitatif eksperimen tersebut peneliti dapat mengendalikan variabel-variabel pengganggu diluar variabel eksperimen sehingga dapat menjelaskan hubungan kausalitas antara variabel eksperimen (perlakuan atau intervensi) dengan efek yang ditimbulkan. Segi kuantitatif, metode yang digunakan dalam penelitian ini memiliki tipe penelitian quasi experimental. Penelitian quasi eksperimental memiliki derajat validitas internal dan eksternal yang rendah dikarenakan tidak memenuhi tiga unsur dari eksperimen sesungguhnya yaitu randomisasi, replikasi, dan perlakuan kontrol.

\section{Prosedur}

Kriteria partisipan penelitian adalah guru SD di Pulai Sebatik, memiliki masa kerja yang beragam mulai dari 1 tahun hingga 15 tahun dan berbagai latar belakang Pendidikan, Belum pernah mendapatkan pelatihan mengenai contextual teaching and learning (CTL) sebagai metode pembelajaran terhadap siswa. Partisipan dipilih berdasarkan hasil penyebaran kuesioner dan memiliki skor kompetensi pedagogik sekolah dasar yang rendah ditunjukkan dengan hasil skor pada saat screening dan pretest.

Penelitian ini juga menggunakan one group pretest posttest design atau istilah lainnya adalah before-after design. Pada penelitian ini, pengukuran terhadap variable terikat dilakukan di awal sebelum bentuk perlakuan diberikan, kemudian pengukuran variable terikat dilakukan kembali setelah perlakuan diberikan. Berikut merupakan tabel desain penelitian one group pretest posttest design. Design ini dapat digambarkan sebagai berikut: 


\section{$\mathrm{O}_{1} \rightarrow \mathrm{X} \rightarrow \mathrm{O}_{2}$}

Keterangan :

O1 : Pengukuran awal (pretest) sebelum perlakuan diberikan

$\mathrm{X}$ : Perlakuan terhadap kelompok eskperimen

O2 : Pengukuran akhir (posttest) sesudah perlakuan diberikan

\section{Pengumpulan Data}

Pengumpulan data dilakukan dengan menyebarkan skala kepada seluruh seluruh peserta pelatihan. Terdapat tiga skala yang digunakan dalam penelitian ini yaitu skala kompetensi pedagogik berbentuk pernyataan yang berkaitan dengan kompetensi pedagogik guru sekolah dasar. Skala kompetensi pedagogik digunakan untuk mengukur kompetensi pedagogik guru sekolah dasar di Pulau Sebatik. Selain itu, pengumpulan data juga dilakukan dengan menggunakan soal pengetahuan berbentuk pertanyaan tertutup multiple choice. Soal pengetahuan digunakan untuk mengukur pengetahuan peserta pelatihan. Pengumpulan data yang ke tiga yaitu pedoman observasi berupa checklist yang disusun berdasarkan teori contextual teaching and learning (CTL).

Langkah-langkah pembelajaran yang diberikan dalam pelatihan berdasarkan Training Need Analysis yang telah dilakukan:

Hari 1:

a. Memahami pembelajaran CTL dalam kurikulum 2013.

b. Memahami strategi penilaian autentik berbasis CTL.

Hari 2:

a. Penyusunan silabus berbasis CTL.

b. Pengembangan RPP berbasis CTL.

c. Praktik mengajar berbasis CTL.

Untuk hari pertama, pelatihan didahului dengan pemberian pre-test, lalu pemberian materi tentang latar belakang, definisi, tujuan, dan kaitannya contextual teaching and learning (CTL) didalam kurikulum 2013. Tujuannya adalah memberikan pengetahuan kepada para peserta agar memiliki persepsi yang sama tentang apa itu CTL. Setelah itu peserta diberikan materi prinsip-prinsip, karakteristik, komponen, dan langkah-langkah pembelajaran CTL serta memberikan video pembelajaran CTL. Hal tersebut bertujuan agar peserta pelatihan tidak hanya mendengar saja materi-materi tentang pembelajaran CTL akan tetapi para peserta juga tau seperti apa itu pembelajaran CTL dengan melihat video tersebut. Peserta juga diberikan materi tentang strategi penilaian Autentik berbasis CTL dan masing-masing peserta diberikan penugasan dengan mengerjakan lembar kerja terkait penilaian autentik tersebut.

Pada hari kedua, peserta cenderung dibekali dengan keterampilan-keterampilan dalam menyusun perencanaan pembelajaran seperti silabus dan RPP, kemudian dilanjutkan dengan praktik mengajar menggunakan pembelajaran CTL, serta ditutup dengan mengisi post-test dan evaluasi pelaksanaan pelatihan. Tujuannya adalah agar para peserta setelah mengikuti pelatihan bisa mengaplikasikan secara langsung pada para siswa di sekolah masing-masing. 


\section{Analisis Data}

Data penelitian dianalisis dengan menggunakan analisa statistik nonparametric uji Wilcoxon signed rank test dengan bantuan SPSS 22.0 for windows. Uji Wilcoxon signed rank test merupakan uji satu sampel bebas pada statistic nonparametric yang memiliki tujuan yang sama dengan Uji-T (Santoso, 2010).

\section{HASIL DAN PEMBAHASAN}

\section{Hasil}

1. Uji Hipotesis

Pengujian hipotesa pada penelitian ini dilakuk _... sngan melakukan pengujian nilai pretest dan posttest skor peserta pada skala kompetensi pedagogik guru sekolah dasar. Berikut adalah hasil analisis wilcoxon skala kompetensi pedagogik guru sekolah dasar yang diberikan kepada 30 subjek penelitian melalui pretest-posttest.

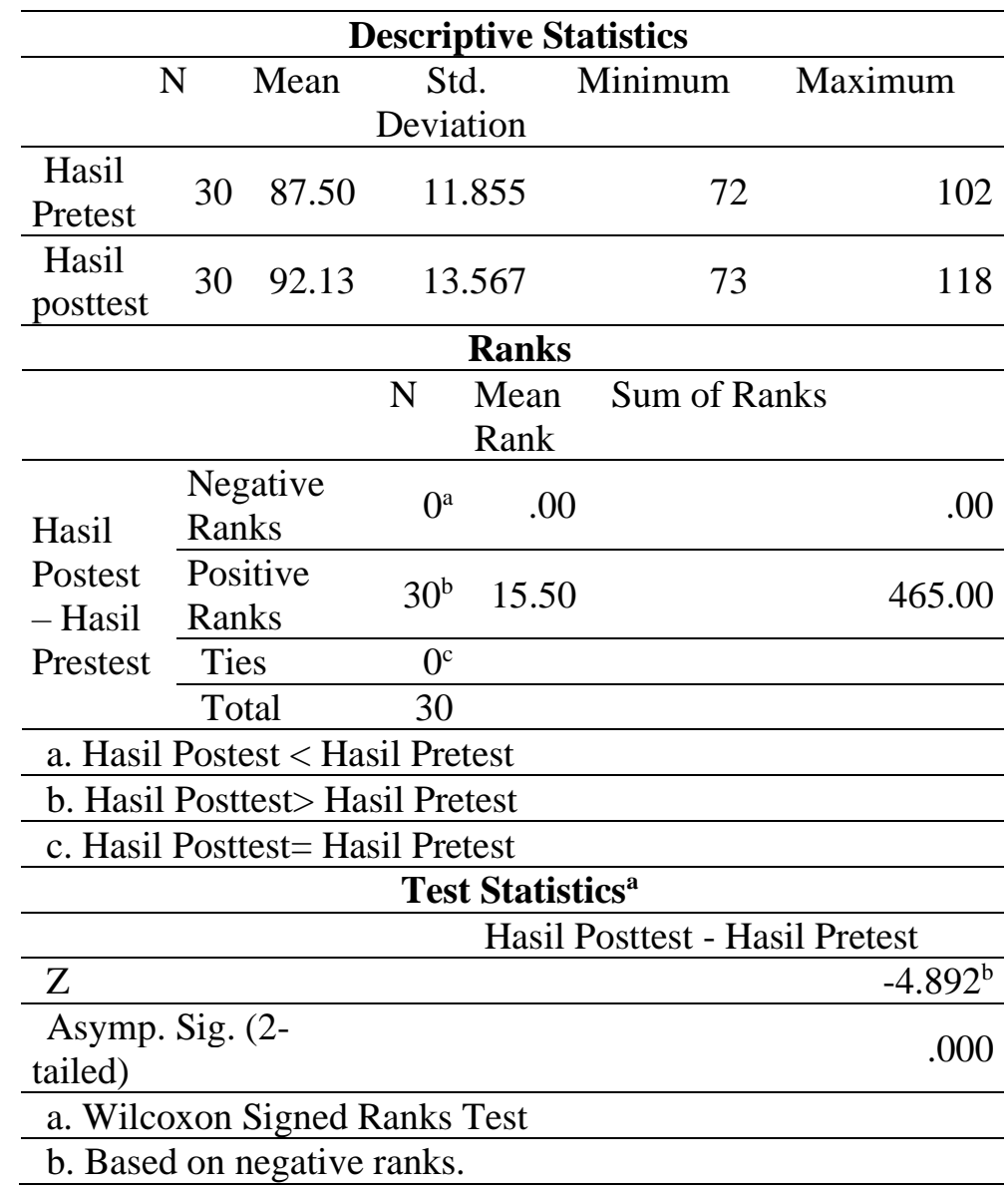

Berdasarkan data di atas, diperoleh nilai sig, (2-tailed) sebesar 0,000 $<0,05$, maka dapat disimpulkan terdapat perbedaan rerata skor kompetensi pedagogik antara hasil pretest peserta pelatihan contextual teaching and learning (CTL) dengan hasil posttest peserta pelatihan contextual teaching and learning (CTL). Hal ini berarti peserta memiliki perubahan yang signifikan dibandingkan sebelum mengikuti pelatihan.

Adapun hal ini bisa dilihat dari perolehan nilai mean pada hasil pretest peserta adalah sebesar 87,50 (M=87,50) sedangkan perolehan nilai mean pada hasil posttest peserta adalah sebesar 92,13 (M=92,13). Sehingga dapat disimpulkan pada penelitian ini bahwa 
pemberian pelatihan contextual teaching and learning (CTL) efektif untuk meningkatkan kompetensi pedagogik guru sekolah dasar di Pulau Sebatik.

2. Hasil Perbandingan pretest dan Posttest

Hasil perbandingan pretest dan posttest dengan menggunakan Teknik Wilcoxon ditunjukkan pada tabel berikut :

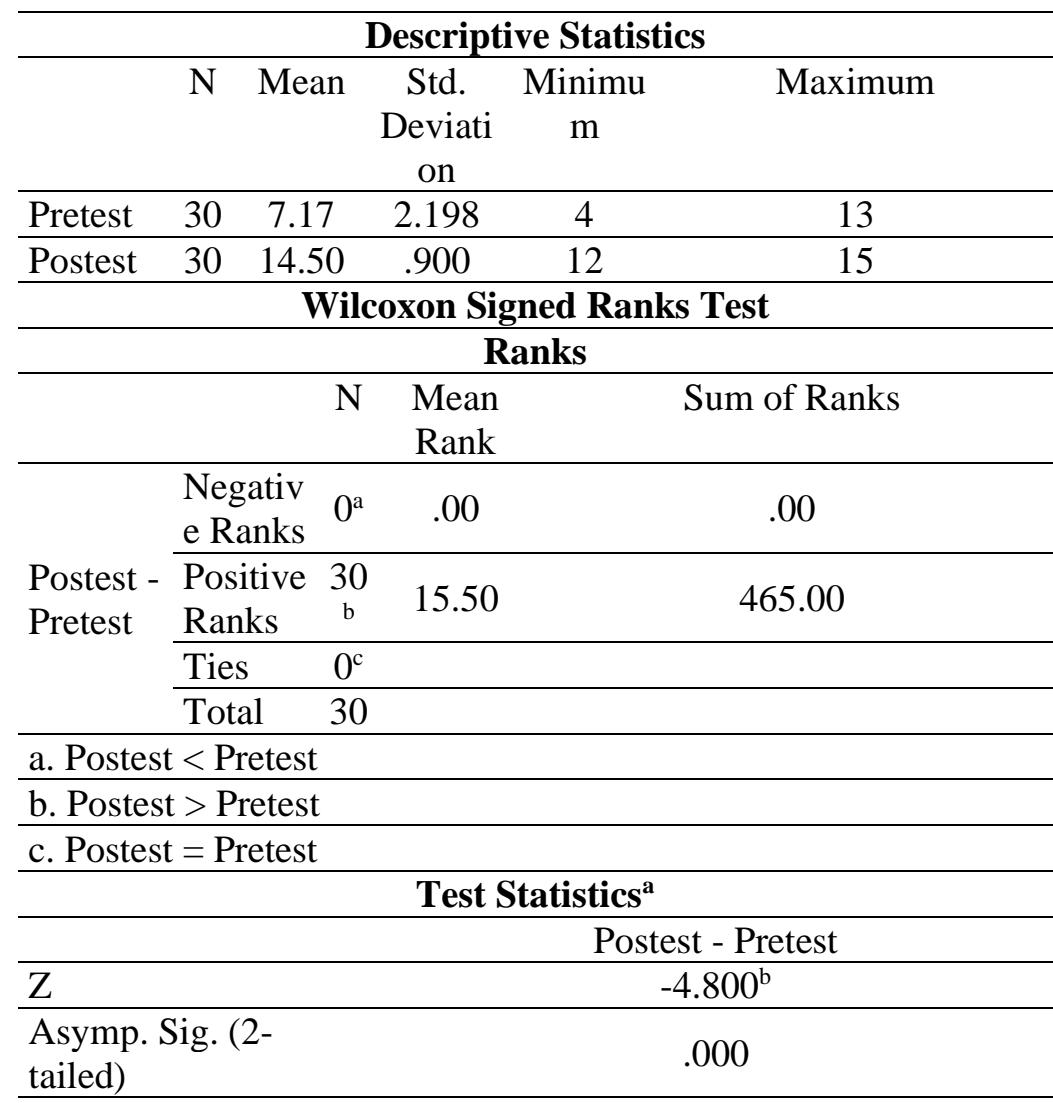

a. Wilcoxon Signed Ranks Test

b. Based on negative ranks.

Berdasarkan data di atas, diperoleh nilai sig, (2-tailed) sebesar 0,000 $<0,05$, maka dapat disimpulkan terdapat perbedaan rerata skor antara hasil tes knowledge pada awal sebelum pelatihan diberikan (pretest) dengan hasil tes knowledge setelah pelatihan (posttest) contextual teaching and learning (CTL) diberikan. Hal ini berarti subjek penelitian memiliki perubahan yang signifikan dibandingkan sebelum mengikuti pelatihan. Adapun hal ini bisa dilihat dari perolehan nilai mean pada hasil pretest subjek penelitian adalah sebesar 7,17 $(M=7,17)$ sedangkan perolehan nilai mean pada hasil posttest adalah sebesar $14,50(M=14,50)$. Sehingga dapat disimpulkan bahwa pemberian pelatihan contextual teaching and learning (CTL) efektif dalam meningkatkan pengetahuan subjek.

\section{Pembahasan}

Hasil penelitian menunjukkan bahwa pelatihan contextual teaching and learning (CTL) dapat meningkatkan kompetensi pedagogik guru sekolah dasar di Pulau Sebatik. Hal ini dibuktikan dengan hasil analisis terkait kompetensi pedagogik yang menggunakan skala likert dengan uji Wilcoxon, diperoleh nilai sig, (2-tailed) sebesar $0,000<0,05$, maka dapat disimpulkan terdapat perbedaan rerata skor kompetensi pedagogik antara hasil pretest peserta 
pelatihan contextual teaching and learning (CTL) dengan hasil posttest peserta pelatihan contextual teaching and learning (CTL).

Hal ini menunjukkan bahwa peserta memiliki perubahan yang signifikan dibandingkan sebelum mengikuti pelatihan. Sebelumnya, rata-rata peserta memiliki kompetensi pedagogik yang rendah. Hal ini dibuktikan dengan hasil nilai UKG dan juga hasil dari pretest. Namun setelah mengikuti pelatihan nampak perubahan terhadap kompetensi pedagogik tersebut. Adapun hal ini bisa dilihat dari perolehan nilai mean pada hasil pretest peserta adalah sebesar $87,50(\mathrm{M}=87,50)$ sedangkan perolehan nilai mean pada hasil posttest peserta adalah sebesar 92,13 ( $M=92,13)$. Sehingga dapat disimpulkan pada penelitian ini bahwa pemberian pelatihan contextual teaching and learning (CTL) efektif untuk meningkatkan kompetensi pedagogik guru sekolah dasar di Pulau Sebatik. Hasil penelitian ini sejalan dengan pendapat Leigh (2006) bahwa pelatihan dapat menghasilkan keterampilan hingga siap untuk bekerja sama dengan pihak lain.

Kemudian dalam penelitian ini peningkatan yang dialami subjek penelitian tidak hanya pada kompetensi pedagogik saja namun juga ditunjukkan oleh hasil evaluasi pelatihan yaitu knowledge. Berdasarkan data tersebut, diperoleh nilai sig, (2-tailed) sebesar 0,000<0,05, maka dapat disimpulkan terdapat perbedaan rerata skor antara hasil tes knowledge pada awal sebelum pelatihan diberikan (pretest) dengan hasil tes knowledge setelah pelatihan (posttest) contextual teaching and learning (CTL)diberikan. Hal ini berarti subjek penelitian memiliki perubahan yang signifikan dibandingkan sebelum mengikuti pelatihan.

Tujuan pelatihan ini juga didukung oleh UU No 14 Tahun 2005 tentang guru dan dosen pasal 14 yang menjelaskan bahwa guru memperoleh kesempatan untuk mengembangkan dan meningkatkan kualifikasi akademik dan kompetensi dan/atau memperoleh pelatihan dan pengembangan profesi lainnya. Sesuai undang-undang tersebut, hasil penelitian ini menunjukkan bahwa pelatihan contextual teaching and learning (CTL) efektif meningkatkan kompetensi guru sekolah dasar di pulau Sebatik khususnya kompetensi pedagogik. Penelitian ini sejalan dengan penelitian Kasno (2017) yang mengemukakan bahwa kegiatan pendampingan menggunakan model pembelajaran contextual teaching and learning (CTL) yang dilakukan oleh kepala sekolah terbukti efektif meningkatkan kompetensi guru kelas V dalam mengajar di SD Negeri 1 Kebonagung UPTD Pendidikan Kecamatan Tegowanu Kabupaten Grobogan.

Hasil penelitian inipun didukung oleh pelatihan yang dilakukan oleh Karim (2017) yang menemukan bahwa pendekatan pembelajaran kontekstual dapat meningkatkan kompetensi guru.. Menurut undang-undang Republik Indonesia No. 14 Tahun 2005 tentang Guru dan Dosen Pasal 10 Kompetensi Pedagogik adalah kemampuan guru dalam mengelola pembelajaran peserta didik. Kemudian diperkuat dengan peraturan Menteri Pendidikan Nasional Republik Indonesia Nomor 16 Tahun 2007 tentang standar kualifikasi akademik dan kompetensi guru pasal 1. Adapun kompetensi pedagogik guru yang disebutkan salah satunya menguasai teori belajar dan prinsip pembelajaran yang mendidik. Oleh karena itu, hasil penelitian ini sejalan dengan peraturan tersebut karena peserta pelatihan mengetahui, memahami, dan mampu menerapkan teori belajar yang sesuai dengan kondisi tempat tinggal serta karakteristik siswa yang ada di Pulau Sebatik.

Pelatihan ini juga memfasilitasi guru untuk belajar sesuai dengan minatnya dan situasi atau masalah-masalah yang dihadapi sehari-hari oleh guru, sehingga guru akan dibekali dengan pengetahuan maupun keterampilan serta sikap untuk menangani masalah-masalah yang dihadapi di kehidupan nyata. Adanya topik atau materi yang sesuai minat dan kebutuhan guru dapat menjadikan pelatihan sebagai pengalaman yang bermakna bagi guru. Hal ini 
dikarenakan guru-guru bersedia untuk belajar dan menemukan pengetahuan dan keterampilan baru yang nantinya dapat digunakan guru di kemudian hari. Hal ini sesuai dengan salah satu pendekatan CTL yang dikemukakan oleh Trianto (2007) yaitu "menemukan". Guru menemukan suatu fenomena yang kemudian mengajak anak didik untuk membiarkan mereka menemukan dan mempelajari temuan mereka sesuai dengan apa yang mereka alami di kehidupan sehari-hari.

\section{KESIMPULAN}

Berdasarkan hasil analisis dan pembahasan dapat ditarik kesimpulan bahwa hipotesis "Pelatihan contextual teaching and learning (CTL) efektif untuk meningkatkan kompetensi pedagogik guru sekolah dasar" dapat diterima. Oleh karena itu, dapat disimpulkan bahwa pelatihan contextual teaching and learning (CTL) efektif dalam mengajar dan mampu meningkatkan pengetahuan dan kompetensi pedagogik guru.

\section{UCAPAN TERIMA KASIH}

Terima kasih kepada Dr. Nono Hery Yoenanto, S.Psi., M.Pd yang telah memberikan arahan dan masukan selama proses penyelesaian penelitian ini, juga pada pihak Dinas Pendidikan Nunukan dan Pulau Sebatik atas bantuannya dalam pengumpulan data.

\section{DAFTAR PUSTAKA}

Depdiknas. (2008). Pendekatan Kontekstual (Contextual Teaching and Learning). Jakarta: Dirjen, Didasmen, Direktorat Sekolah Lanjutan Pertama.

Fadhila, Efendi, M.Z.,\& Ridwan. (2017). Analysis of contextual teaching and learning (CTL) in the course of applied physics at the mining engineering department. International Journal of Science and Applied Science. Vol. 1, (1), 25-32.

Karim, A. (2017). Analisis pendekatan pembelajaran CTL (Contextual teaching and learning) di SMPN 2 Jamber Timur karawang. Jurnal ilmiah Pendidikan MIPA.Vol, 7,(2). ISSN 25025457.

Kasno (2017). Upaya meningkatkan kompetensi guru melalui pendampinga guru pada implementasi pembelajaran contextual teaching and learning/CTL pada sekolah dasar. Jurnal Pendidikan ilmiah. Vol 3, (8). 123-129.

Kementerian Pendidikan Nasional. (2003). UU Nomor 20 Tahun 2003 tentang Sistem Pendidikan Nasional. Undang-Undang Republik Indonesia Nomor 20 Tahun 2003 Tentang Sistem Pendidikan Nasional Dengan Rahmat Tuhan Yang Maha Esa Presiden Republik Indonesia.

Komalasari, K.(2012). The Effect Of Contextual Learning in Civic Education on Students' Civic Skills. Internasional Journal for Educational Studies.

Leigh, D. (2006). The group trainers handbook: Designing and delivering training for groups (3rd ed.). London: kogan Page.

Mudlofir, A. (2012). Pendiidk Profesional; Konsep, Strategi, dan Aplikasinya dalam Peningkatan Mutu Pendidik di Indonesia. Jakarta: Rajawali Pers

Mulyasa, E. (2009). Standar Kompetensi dan Sertifikasi Guru. Bandung: PT Remaja . 
Nurhaedah. (2012). Ibm Pendekatan Kontekstual (Contextual Teaching and Learning) Dalam Pembelajaran Bagi Guru-Guru di SDN Inpres Bira 2 Botoa Makassar. Journal Publikasi; Vol, 2, (2). 152-159.

Ramayulis. (2013). Profesi dan Etika Keguruan. Jakarta: Kalam Mulia

Santoso, S. (2003). Mengatasi berbagai masalah statistic dengan SPSS versi 11.5. Jakarta : PT. Elex Media Komputindo.

Trianto. (2007). Inovasi Pembelajaran. Jakarta: Rineka Cipta. 